\title{
THE THERMAL DEPENDENCE OF LIZARD BEHAVIOUR
}

\author{
BY ALBERT F. BENNETT \\ School of Biological Sciences, University of California, Irvine, California 92717
}

\begin{abstract}
New techniques were utilized to measure burst speed and distance running capacity in six species of lizards and to examine the thermal dependence of these behavioural capacities. These behaviours were repeatable among groups of animals within a species, within a group during the experiments, and among individuals of a group. Burst speeds averaged 130 to $150 \mathrm{~m} / \mathrm{min}$ for active species, with some individuals exceeding $200 \mathrm{~m} / \mathrm{min}$. Total distances run during 2 min averaged 60 to $70 \mathrm{~m}$ in species with the greatest stamina. Thermal dependence of these behaviours was low or absent $\left(Q_{10} \leqslant 1.5\right)$ over the normal range of active body temperatures, and performance was not necessarily maximal at normally experienced body temperatures. These processes have much less thermal dependence than do most physiological processes and suggest adaptations to maintain functional behavioural capacity over a broad range of body temperature.
\end{abstract}

Behaviour is the result of complex and integrated physiological processes. These involve numerous individual events in the central and peripheral nervous systems and in the skeletal musculature, all of which are dependent upon biochemically controlled rate processes. A primary external factor controlling these physiological processes is the temperature at which they occur. Most biochemical and physiological reactions have a pronounced thermal dependence and double or triple in rate whenever temperature is increased $10 \mathrm{C}$ (written $Q_{10}=2-3$ ) (Precht et al. 1955; Prosser 1973). If quantitative aspects of behaviour were similarly dependent upon body temperature, the consequences for performance capacities would be striking. An animal with a body temperature of $20 \mathrm{C}$ would be able to run only 10 to $25 \%$ as fast as an animal with a temperature of $40 \mathrm{C}$. Homeothermic animals, by physiologically stabilizing body temperature, avoid these thermal effects. Poikilotherms, however, must contend with varying temperatures. The influence that thermal variation exerts on behavioural performance in these animals has received little attention, in spite of the fact that it might be expected to be a significant factor. In the absence of data, predictions concerning the thermal dependence of behaviour in poikilotherms are not particularly easy. On one hand, the general thermal dependence of most physiological reactions suggests that behaviour should have a similar dependence. On the other, one might hypothesize that the selective importance of appropriate behaviour is great enough to have resulted in the evolution of adaptations that minimize the influence of body temperature on behavioural processes. In the latter case, the performance capacities of a poikilothermic ani- mal would be relatively constant over a range of body temperatures. Experiments addressing the thermal dependence of behaviour would seem to constitute a rewarding line of investigation.

Lizards are particularly interesting animals in regard to an examination of the influence of body temperature on behaviour. Some species live and forage under cover and experience little diurnal temperature variation. Others bask in the sun during the day and regulate their body temperatures at high levels by behaviour (Cowles \& Bogert 1944; Cloudsley-Thompson 1971). These latter animals may undergo daily cycles in body temperatures of $25 \mathrm{C}$ or more. In addition, they must expose theniselves when body temperature is still low in order to heat to preferred thermal levels. Consequently, lizards as a group exhibit considerable diversity in thermoregulatory pattern, and interspecific examinations may be expected to reveal the extent to which thermal compensation of behaviour is possible and appropriate. Another feature of saurian thermobiology of interest is the functional significance of preferred body temperature. Behaviourally regulated temperatures in sun-basking animals are maintained with considerable precision and are fairly constant within genera (Cowles \& Bogert 1944; Brattstrom 1965). Given the stability of these thermal levels, it has generally been assumed that optimization or maximization of function occurs at preferred or field active body temperatures in lizards. These functional correlates have been elusive in laboratory experiments (see reviews by Dawson 1967, 1975). A central question for the thermobiology of reptiles is the extent to which behavioural capacities are maximized at body temperatures occurring during normal activity. 
The behavioural capacities of lizards are strongly limited by their metabolic support systems. They cannot attain or sustain high levels of oxygen consumption. Consequently, any activity greater than a slow walk must be fuelled by non-sustainable anaerobic metabolism (Bennett \& Licht 1972; Bennett \& Dawson 1976; Bennett 1978). They exhaust readily at even moderate speeds and frequently undertake only burst activity of short duration. Rapid escape behaviour is characteristic of these animals when pursued. The following experiments measure performance during two modes of running behaviour: burst speed and distance capacity. Burst speed as examined here is the average velocity attained by running from a standing start over a distance of $2 \mathrm{~m}$. This measure is realistic in approximating an escape attempt under natural conditions, in which an animal runs to cover over comparably short distances. Distance capacity is measured as the total distance run during 2 min of constant pursuit. It is used as a measure of work capacity over a relatively short but ecologically relevant time period to indicate stamina during long pursuit, territorial defence, or courtship. These are measurements of the greatest capacity for activity that these lizards possess and consequently set an upper limit on the quantitative aspects of the behaviour of these animals. The thermal dependence of these factors and their correlation with preferred body temperature are measured in six species of small lizards of diverse thermal preferenda.

\section{Materials and Methods}

The following lizards were used in this study. All are adult animals of mixed sexes, except as indicated. Date indicates month of running experiment.
Cnemidophorus murinus; 14 animals, $\bar{x}$ mass

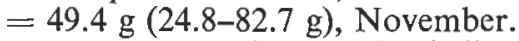

Dipsosaurus dorsalis, 20 animals (juveniles and adults), $\bar{x}$ mass $=29.8 \mathrm{~g}(12.7-57.0 \mathrm{~g})$, August; 40 animals, $\bar{x}$ mass $=38.3 \mathrm{~g}(27.3-50.4 \mathrm{~g})$, October.

Eumeces obsoletus, 6 animals, $\bar{x}$ mass $=25.6 \mathrm{~g}$ (20.0-33.4 g), June.

Gerrhonotus multicarinatus, 12 animals, $\bar{x}$ mass

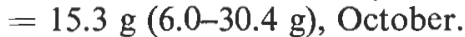

Sceloporus occidentalis, 17 animals, $\bar{x}$ mass $=$

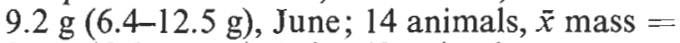
$9.5 \mathrm{~g}(6.6-13.1 \mathrm{~g})$, July; 40 animals, $\bar{x}$ mass $=$ $13.8 \mathrm{~g}(10.9-18.4 \mathrm{~g})$, October; 12 animals, $\bar{x}$ mass $=11.3 \mathrm{~g}(5.6-17.9 \mathrm{~g})$, December.

Uma inornata, 11 animals, $\bar{x}$ mass $=19.3 \mathrm{~g}$ (9.1-32.8 g), September.

Cnemidophorus is an actively foraging herbivore in an open thorn scrub habitat and has a high body temperature characteristic of the genus. Dipsosaurus is also a high-temperature herbivore, living with Uma in sandy deserts. Sceloporus is a common insectivorous lizard in oak-woodland and chapparal habitats. Eumeces and Gerrhonotus are reclusive species, the former living under rocks in the Great Plains area and the latter foraging under the leaf litter and in vegetation. Cnemidophorus were originally collected in Bonaire, Netherlands Antilles, and were maintained in the laboratory for several months prior to running. Eumeces were collected in Kansas and all other species were collected in Southern California (California Scientific Collectors Permits No. 1181-1977 and 1067-1978).

Body temperatures selected under laboratory conditions and obtained from animals of these species active in the field are reported in Table I. Data on the Eumeces and Gerrhonotus used in this study were obtained in a radiant-heated sand

Table I. Body Temperatures of Lizards in Thermal Gradients and Active in Natural Enviromments

\begin{tabular}{|c|c|c|c|}
\hline Species & $\begin{array}{l}\text { Preferred in } \\
\text { laboratory } \\
\text { (C) }\end{array}$ & $\begin{array}{l}\text { Field active } \\
\text { (C) }\end{array}$ & Reference \\
\hline Cnemidophorus & - & 40.4 & Bennett \& Gorman 1979 \\
\hline Dipsosaurus & 38.5 & $40.0-42.0$ & $\begin{array}{l}\text { Norris } 1953 \\
\text { Brattstrom } 1965 \\
\text { DeWitt } 1967\end{array}$ \\
\hline Eumeces & $22.7 * ; 33.2$ & 27.1 & Fitch 1955 \\
\hline Gerrhonotus & $26.2 *$ & 24.3 & Brattstrom 1965 \\
\hline Sceloporus & $34.1-35.0$ & 35.0 & $\begin{array}{l}\text { Brattstrom } 1965 \\
\text { McGinnis } 1966\end{array}$ \\
\hline Uma & 37.0 & 38.6 & Brattstrom 1965 \\
\hline
\end{tabular}

*Experimental animals from this study. 
temperature gradient by hourly measurements of cloacal temperature with a quick-registering thermometer. Neither of these species are sun-basking animals (heliotherms) as are the others, and consequently they have much lower field-active body temperatures.

All animals except Cnemidophorus were held in glass aquaria for only one week prior to experimentation. They had continuous access to water and food (Tenebrio larvae, dog food, and lettuce). A photothermal gradient was available for regulation of body temperature during the day (0600 to 1800 hours); nocturnal temperature was $25 \mathrm{C}$.

During experimentation, the animals were kept in an aquarium inside a large $\left(12 \mathrm{~m}^{2}\right)$ controlled temperature chamber in which the runs were conducted. Chamber temperature was regulated at $25 \mathrm{C}$ between 1000 and 0400 hours local time of the following day; a 250-W light bulb in the aquarium was lit between 1000 and 1800 hours, providing a source of heat for behavioural maintenance of body temperature. The chamber was set at the experimental test temperature from 0400 to 1000 hours, and animals were run at 0800 to 0900 hours. Fluorescent lights in the chamber maintained a photoperiod of 0600 to 1800 hours. Consequently, body temperature was set at the desired level during the morning experimental period, and the animals were free to regulate body temperature behaviourally for the remainder of the photophase.

Burst running speed was measured in a 2.4-m straight track constructed of plywood. Its walls were $30 \mathrm{~cm}$ high and painted white; the floor was $10 \mathrm{~cm}$ wide and covered with a linen cloth. Two photocells were positioned $2.00 \mathrm{~m}$ apart on the track. The first photocell activated an electronic stopwatch (Data Precision Model 5740) that displayed time in 0.01 -s intervals. The second photocell stopped the watch. An animal was set on the track and chased by hand toward the end of the track. This was covered with a dark bag that provided concealment. The lizards generally ran toward the bag immediately upon release and required pursuit only at low body temperatures. Animals were given three running trials in sequence per day on the track. The greatest speed attained is reported; this was approximately $15 \%$ higher than the mean of the three trials.

Distance running ability was measured in an oval track $7.6 \mathrm{~m}$ in circumference constructed about the perimeter of the temperature cabinet. It had cardboard walls $30 \mathrm{~cm}$ high and was 11 $\mathrm{cm}$ wide. The flooring was wide-mesh rubber matting covered with beach sand. An experimenter stood by each half of the track and chased the animal from its starting point by hand and with a feather-covered prod. Distance covered over 1- and 2-min intervals was measured and reversal of direction or other characteristic behaviours were recorded. At high body temperatures, the lizards generally ran the circuit several times with no assistance, and prodding was required only during the second minute of activity.

Only one task, either three burst runs or one distance run, was assigned during a day so that the animals were not fatigued by frequent experimentation. Animals were first tested for burst running speed at field-active body temperatures for several days until no further improvement in performance was obtained; a maximum of three days was sufficient to produce no further improvement. Distance run at that temperature was then measured. Daily trials were then alternated between burst speeds and distance runs as body temperature was varied in a random sequence of $5 \mathrm{C}$ intervals. After the thermal range over which locomotion was maintained was measured, the animals were returned to their field-active body temperature and performance was measured again. Final values of performance are reported for these repeated measurements.

Non-parametric statistics are used to evaluate differences in performance, since variation about mean values was sometimes temperature-dependent and heteroscedastic. Two-tailed tests have been used; significance is judged as $P \leq$ 0.05 . Since much of the variation is due to individual differences, paired tests have been used within groups of animals. The tests are abbreviated as follows: FANOVA, Friedman two-way analysis of variance; KCC, Kendall coefficient of concordance; MWUT, Mann-Whitney $U$ test; SRCC, Spearman rank correlation coefficient; WSRT, Wilcoxon signed-rank test (Siegel 1956).

\section{Results \\ Repeatability of Performance}

Performance in both burst speed and distance run trials was very consistent for what might otherwise be considered highly variable functions. This consistency was evident (1) between performances on different days within a single group of animals, (2) between different groups of animals of the same species, and (3) between individuals of a group measured either at a single 
body temperature or over a range of temperatures. Each of these comparisons is discussed below.

Mean values of burst speed did not change when animals were run repeatedly at the same body temperature for several days. The results of such a trial are reported in Table II for Sceloporus. There is a significant increase in performance from day 1 to day $2(P=0.01$, WSRT $)$ but there is no further significant change in performance, whether the data are analysed on a day-to-day basis $(P>0.25$, WSRT) or as a whole $(P=0.9$, FANOVA). A similar increment after the first day's trial with no further change in subsequent performance was also found in two other monthly samples of Sceloporus, and in Cnemidophorus and Dipsosaurus. No change over the entire trial, including day 1 , occurred in Gerrhonotus or Uma. In some species there

Table II. Burst Speed in Sceloporus occidentalis $\left(T_{B}=35 \mathrm{C}, N=14\right.$, July)

\begin{tabular}{cr}
\hline Day of trial & \multicolumn{1}{c}{$\mathrm{m} / \mathrm{min} \pm \mathrm{SE}$} \\
\hline 1 & $77.6 \pm 5.6$ \\
2 & $96.9 \pm 9.4$ \\
3 & $106.0 \pm 10.4$ \\
4 & $112.9 \pm 16.2$ \\
5 & $114.2 \pm 12.9$ \\
18 & $105.8 \pm 11.0$ \\
\hline
\end{tabular}

appears to be a requirement for familiarization with the experimental raceway. However, this is achieved in single exposure and no evidence of a training effect is apparent over the course of these runs. A lack of training effect has been previously reported for small lizards (Gleeson 1979). No change in distance running ability of Sceloporus or Cnemidophorus occurred over the course of the experiments. That of Dipsosaurus declined slightly (about $10 \%$ ) and that of Gerrhonotus increased $24 \%$. In both cases these changes are significant $(P<0.04$, WSRT $)$. Final performance values are reported in subsequent analyses.

Different groups of animals within a species collected during the same season had very similar mean levels of performance. Distance running ability in four independent samples of Sceloporus are reported in Table III. There are no significant differences among groups at any single body temperature in these samples $(P>0.1$, MWUT, FANOVA). Likewise, independently sampled groups of Dipsosaurus measured at $40 \mathrm{C}$ had similar performances $(59.0 \mathrm{~m} / 2 \mathrm{~min} \pm 2.9 \mathrm{SE}$, $N=20$, Aug. $1977 ; 62.9 \pm 1.4 \mathrm{SE}, N=40$, Sept. $1978 ; P=0.2$, MWUT). Burst running performance also does not vary significantly among the different groups of lizards collected during the same season, as is reported in Table IV. The

Table III. Distance Running Performance in Separate Groups of Sceloporus occidentalis Caught during Different Months $($ Run $=2$ min) (mean $\pm \mathrm{SE})$

\begin{tabular}{|c|c|c|c|c|c|c|c|}
\hline & & & & & $\operatorname{tance}$ run $(r$ & & \\
\hline & & $N$ & $10 \mathrm{C}$ & $20 \mathrm{C}$ & $30 \mathrm{C}$ & $35 \mathrm{C}$ & $40 \mathrm{C}$ \\
\hline 1977 & June & 17 & 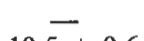 & $28.6 \pm 1.3$ & $37.1 \pm 1.6$ & $40.6 \pm 1.6$ & 一 \\
\hline & July & 14 & $10.5 \pm 0.6$ & $27.5 \pm 1.7$ & $37.2 \pm 2.8$ & $40.1 \pm 2.3$ & $33.6 \pm 3.0$ \\
\hline & Dec. & 12 & $10.2 \pm 0.9$ & $29.6 \pm 1.7$ & $41.1 \pm 2.8$ & $42.5 \pm 2.7$ & $38.5 \pm 2.3$ \\
\hline 1978 & Oct. & 40 & - & - & - & $41.3 \pm 1.3$ & 一 \\
\hline
\end{tabular}

Table IV. Burst Speed in Different Groups of Lizards

\begin{tabular}{llccr}
\hline \multicolumn{1}{c}{ Species } & Date & $\begin{array}{c}\text { Temperature } \\
(\mathrm{C})\end{array}$ & $\begin{array}{c}\text { Speed (m/min) } \\
(\bar{x} \pm \mathrm{SE})\end{array}$ & $N$ \\
\hline Dipsosaurus dorsalis & Aug. 1977 & 40 & $129.5 \pm 4.3$ & 20 \\
& Sept. 1978 & 40 & $132.0 \pm 3.4$ & 40 \\
Gerrhonotus multicarinatus & Sept. 1977 & 30 & $52.1 \pm 5.6^{*}$ & 5 \\
& Oct. 1977 & 30 & $51.2 \pm 3.5^{*}$ & 12 \\
Sceloporus occidentalis & July 1977 & 35 & $105.8 \pm 11.0$ & 14 \\
& Dec. 1977 & 35 & $142.4 \pm 10.9$ & 12 \\
& Oct. 1978 & 35 & $146.0 \pm 4.0$ & 40
\end{tabular}

*First day of trial. 
only difference occurs between the summer and autumn samples of Sceloporus, the burst speed of the former being less than that of the combined fall samples $(P<0.001$, MWUT). Apart from seasonal differences, independently sampled groups have almost identical performances for both burst and distance activity.

The variance about mean running speeds is due principally to variation in running performance of individual animals. The rank order of this individual performance is very conservative: the fastest animals retain their rank position at all body temperatures and at repeated trials at the same temperature, and slow animals remain slow. Representative rank order data for burst speed in Gerrhonotus over a range of body temperatures are given in Table V. The rank order of this performance in Gerrhonotus has a highly significant individual component $(P<0.001$, $\mathrm{KCC}$ ). The rank ordering of individual performance of all species examined for both burst running speed and distance capacity is significant $(P<0.01, \mathrm{KCC})$ for individuals of all six species.

The behaviours tested in these experiments appear to be highly repeatable and consistent among individuals of a single group, between groups, and within a group over the course of the experiments. Consequently, they can serve in a quantitative analysis of the effect of body temperature on performance capacity.

\section{Burst Speed}

Maximal observed burst speeds are reported in Table VI. Speeds of several individuals exceed $200 \mathrm{~m} / \mathrm{min}(=12 \mathrm{~km} / \mathrm{h})$, and the maximum recorded observation was $272 \mathrm{~m} / \mathrm{min}(=16.3 \mathrm{~km} /$ h) by a Sceloporus at $40 \mathrm{C}$. Average speeds for species active at high body temperatures (Cnemidophorus, Dipsosaurus, Sceloporus, Uma) are 130 to $150 \mathrm{~m} / \mathrm{min}$, although the reclusive species (Eumeces, Gerrhonotus) are considerably less than that. There is a great range of individual performance: under nearly all circumstances there are some individuals that are at least twice as fast as others under identical conditions. As stated previously, these individual differences are maintained consistently throughout the trials.

Definite differences exist among species in the thermal range over which locomotor ability is maintained. The lizards Cnemidophorus and Dipsosaurus, both thermophilic animals with field active temperatures of 40 to $42 \mathrm{C}$, maintain a coordinated escape response up to $44 \mathrm{C}$. However, they become incapacitated below $20 \mathrm{C}$ and are incapable of escape with lower body temperatures. In contrast, Gerrhonotus and Sceloporus maintain functional burst activity even at $10 \mathrm{C}$, but cannot tolerate temperatures above 37.5 and $40 \mathrm{C}$, respectively.

For all species examined, high levels of activity are attained at $30 \mathrm{C}$, and further increments in temperature up to lethal levels do not greatly improve performance. Temperature coefficients,

$$
Q_{10}=\left(\frac{R_{2}}{R_{1}}\right)^{\frac{10}{T_{2}}}-T_{1}
$$

(where $R_{2}$ and $R_{1}$ are rate functions at temperatures $T_{2}$ and $T_{1}$, respectively, and $T_{2}>T_{1}$ (T in C)) above $30 \mathrm{C}$, are below 1.5 for all species, and most are not different from 1.0 (WSRT), indicating thermal independence (Table VII). Even between 20 and $30 \mathrm{C}$ only Cnemidophorus and Dipsosaurus have temperature coefficients characteristic of most biochemical and physiological rate processes $\left(Q_{10}=2-3\right)$.

\section{Distance Run}

The distance attained by the lizards during runs of 1- and 2-min duration are reported in Table VIII. The animals could not sustain the

Table V. Rank Order of Individual Burst Speeds in Gerrhonotus multicarinatus ( $N=12$, rank $1=$ slowest)

\begin{tabular}{|c|c|c|c|c|c|c|c|c|c|c|c|c|}
\hline \multirow{2}{*}{$\begin{array}{l}\text { Temperature } \\
\text { (C) }\end{array}$} & \multicolumn{12}{|c|}{ Individual } \\
\hline & $\mathbf{A}$ & B & $\mathrm{C}$ & $\mathrm{D}$ & $\mathbf{E}$ & $\mathrm{F}$ & $\mathrm{G}$ & $\mathrm{H}$ & $\mathbf{I}$ & $\mathbf{J}$ & $\mathbf{K}$ & $\mathbf{L}$ \\
\hline 10 & 5 & 6 & 10 & 2 & 9 & 3.5 & 12 & 3.5 & 11 & 8 & 1 & 7 \\
\hline 15 & 5 & 8 & 12 & 2 & 10 & 7 & 11 & 3 & 6 & 4 & 1 & 9 \\
\hline 20 & 6 & 7 & 11 & $\overline{2}$ & 10 & 4.5 & 8 & 4.5 & 12 & 9 & 1 & 3 \\
\hline 25 & 4 & 5 & 11 & 2 & 10 & 9 & 7 & 6 & 12 & 1 & 3 & 8 \\
\hline 30 & 7 & 4 & 11 & 1 & 5.5 & 8 & 9 & 3 & 12 & 5.5 & 2 & 10 \\
\hline 35 & 5 & 3 & 6 & 2 & 7.5 & 11 & 9 & 4 & 12 & 7.5 & 1 & 10 \\
\hline 37.5 & 4 & 5 & 6 & 2 & 7 & 9.5 & 12 & 3 & 11 & 9.5 & 1 & 8 \\
\hline
\end{tabular}


Table VI. Burst Speeds in Small Lizards

\begin{tabular}{|c|c|c|c|c|c|c|c|c|c|}
\hline \multirow[b]{2}{*}{ Species } & \multicolumn{9}{|c|}{ Burst speeds (m/min) } \\
\hline & 10 & 15 & 20 & 25 & 30 & 35 & 37.5 & 40. & $43-44$ \\
\hline \multicolumn{2}{|c|}{$\begin{array}{l}\text { Cnemidophorus } \\
(N=14)\end{array}$} & - & $\begin{array}{l}38.4 \pm 5.9 \\
(7.4-88.2)\end{array}$ & $\begin{array}{rr}112.8 \pm \quad 6.8 \\
(68.2-148.1)\end{array}$ & $\begin{array}{l}123.5 \pm 9.0 \\
(60.9-173.9)\end{array}$ & $\begin{array}{r}131.3 \pm 10.4 \\
(58.0-187.5)\end{array}$ & - & $\begin{array}{r}146.9 \pm 5.4 \\
(110.1-169.0)\end{array}$ & $\begin{array}{c}134.0 \pm 10.5 \\
(46.5-179.1)\end{array}$ \\
\hline \multicolumn{2}{|c|}{$\begin{array}{l}\text { Dipsosaurus } \\
(N=20)\end{array}$} & $\begin{array}{l}4.8 \pm 0.4 \\
(3.3-6.3)\end{array}$ & $\begin{array}{l}38.6 \pm 4.8 \\
(12.2-90.2)\end{array}$ & $\begin{array}{l}79.4 \pm 5.4 \\
(35.3-118.8)\end{array}$ & $\begin{array}{l}95.3 \pm 4.3 \\
(66.3-122.4)\end{array}$ & $\begin{array}{c}110.6 \pm 4.4 \\
(85.1-150.0)\end{array}$ & - & $\begin{array}{l}129.5 \pm 4.3 \\
(89.6-169.0)\end{array}$ & $\begin{array}{l}128.9 \pm 5.3 \\
(78.4-169.0)\end{array}$ \\
\hline \multicolumn{2}{|l|}{$\begin{array}{l}\text { Eumeces } \\
(N=6)\end{array}$} & - & $\begin{array}{l}51.8 \pm 8.1 \\
(13.2-71.4)\end{array}$ & - & $\begin{array}{l}94.0 \pm 6.2 \\
(75.0-110.1)\end{array}$ & - & - & - & - \\
\hline \multicolumn{2}{|c|}{$\begin{array}{l}\text { Gerrhonotus } \\
(N=12) \quad 9.9 \pm 0.7 \\
\end{array}$} & $\begin{array}{c}20.9 \pm 1.9 \\
(11.2-32.2)\end{array}$ & $\begin{array}{c}35.5 \pm 2.9 \\
(19.8-55.6)\end{array}$ & $\begin{array}{c}49.5 \pm 3.9 \\
(31.9-76.9)\end{array}$ & $\begin{array}{c}59.9 \pm 7.2 \\
(31.7-126.3)\end{array}$ & $\begin{array}{c}64.5 \pm 6.0 \\
(34.6-101.7)\end{array}$ & $\begin{array}{c}67.0 \pm 5.8 \\
(34.7-99.2)\end{array}$ & - & - \\
\hline \multicolumn{10}{|l|}{$\begin{array}{l}\text { Sceloporus } \\
\text { July }\end{array}$} \\
\hline$(N=14)$ & $\begin{array}{l}12.6 \pm 1.3 \\
(8.3-23.7)\end{array}$ & $\begin{array}{l}41.3 \pm 5.2 \\
(21.9-73.6)\end{array}$ & $\begin{array}{l}69.0 \pm 6.9 \\
(31.2-114.3)\end{array}$ & $\begin{array}{l}95.0 \pm 7.8 \\
(61.9-134.8)\end{array}$ & $\begin{array}{l}110.4 \pm 12.0 \\
(60.9-171.4)\end{array}$ & $\begin{array}{l}105.8 \pm 11.0 \\
(46.3-193.5)\end{array}$ & - & $\begin{array}{l}121.9 \pm 24.9 \\
(48.4-210.5)\end{array}$ & - \\
\hline$(N=12)$ & $\begin{array}{c}17.6 \pm 1.5 \\
(8.8-25.5)\end{array}$ & - & $\begin{array}{l}70.5 \pm 7.1 \\
(26.0-113.2)\end{array}$ & - & $\begin{array}{l}132.7 \pm 6.2 \\
(90.2-162.2)\end{array}$ & $\begin{array}{l}142.4 \pm 10.9 \\
(106.2-230.8)\end{array}$ & - & $\begin{array}{l}150.6 \pm 14.1 \\
(98.4-272.4)\end{array}$ & - \\
\hline $\begin{array}{l}U_{(N=11)} \\
(N=11\end{array}$ & - & - & $\begin{array}{l}85.1 \pm 7.0 \\
(28.6-111.1)\end{array}$ & $\begin{array}{l}105.3 \pm 8.6 \\
(47.4-142.9)\end{array}$ & $\begin{array}{l}132.6 \pm 6.7 \\
(85.1-169.0)\end{array}$ & $\begin{array}{l}138.7 \pm 8.3 \\
(71.4-173.9)\end{array}$ & $\begin{array}{l}150.0 \pm 6.5 \\
(112.1-190.5)\end{array}$ & $\begin{array}{l}157.9 \pm 9.1 \\
(92.3-210.5)\end{array}$ & $\begin{array}{c}152.0 \pm 8.7 \\
(100.0-196.7)\end{array}$ \\
\hline
\end{tabular}

Mean values \pm SE and (ranges) are reported for each body temperature. 
straight-away burst speeds reported in Table VI. Although several Sceloporus had burst speeds over $200 \mathrm{~m} / \mathrm{min}$, the greatest actual distance attained by an individual was $46 \mathrm{~m}$ during the first minute's run. The average performance over 1 min was only 30 to $40 \%$ of burst speed. Speed decreased steadily during the run, and animals showed noticeable fatigue by the end of the second minute. In general, they ran only $30 \%$ as far during the second minute as during the first.

There is a pronounced difference in stamina among the species. At high body temperatures, Cnemidophorus, Dipsosaurus, and Eumeces ran 60 to $70 \mathrm{~m}$ in $2 \mathrm{~min}$, with individual animals approaching $100 \mathrm{~m}$. In comparison, Gerrhonotus and Sceloporus ran only about half that distance and were more visibly exhausted by the runs than were the former species. Gerrhonotus and Sceloporus, however, maintained locomotor activity at much lower body temperatures.

The thermal dependence of these distance runs is very similar to that of burst speeds (Table VII). At $30 \mathrm{C}$ and above, $Q_{10}$ values are $\leq 1.5$ for all species. Eumeces, Gerrhonotus, and Sceloporus show only a modest temperature dependence in stamina even between 20 and $30 \mathrm{C}$.

Gerrhonotus, the animal with the least distance running ability, was also the one with the most elaborate defensive repertoire of behaviours. When pursued, animals would often turn and bite or turn rapidly, lower the head, and wave the tip of their tail in a sinuous manner. They often defaecated when handled. Tail breakage was most common in Gerrhonotus and Sceloporus, and no tail breaks occurred in Cnemidophorus or Eumeces. The species with greater endurance did not show threat behaviours but ran steadily or reversed rapidly and ran in the opposite direction in the track. These observations support those of Tucker (1967), who hypothesized that lizards of lower aerobic scope and work capacity rely more heavily on static defence postures than on rapid escape manoeuvres.

\section{Correlations of Individual Performance}

The consistent performance of individual animals is not generally correlated with size differences among them. Among adult animals measured at field-active body temperatures, there is no relationship between body mass and burst speed in Cnemidophorus, Dipsosaurus, Eumeces, Sceloporus, or Uma ( $P>0.05, \mathrm{SRC})$. Only in Gerrhonotus is burst speed positively related to body size $(P<0.05$, SRC). Distance capacity is also independent of mass in Cnemidophorus, Dipsosaurus, and Sceloporus $(P>0.05$, SRC), but these factors are positively related in Eumeces and Gerrhonotus $(P<0.05$, SRC).

In Sceloporus, the only species easily sexed by external characters, there is no significant difference between the sexes in either burst performance $(P=0.5$, MWUT $)$ or distance capacity $(P=0.8$, MWUT $)$.

The correlation between burst run and distance run abilities among individuals of a species are complex. Spearman rank correlation coefficients relating these factors are presented in Table IX. A positive correlation indicates that a good burst runner is also a good distance runner: a negative correlation indicates that good burst running ability is related to poor distance ability. These relationships have a thermal dependence. At low body temperatures, the two abilities are positively related. As body temperature increases, this correlation disappears, and at field active temperatures there is no association between the factors. Thus under normally active conditions, performance in one activity mode

Table VII. The Thermal Dependence of Activity in Small Lizards

\begin{tabular}{|c|c|c|c|c|c|}
\hline \multirow[b]{2}{*}{ Species } & \multicolumn{5}{|c|}{$Q_{10}$} \\
\hline & $10-20 \mathrm{C}$ & $20-30 \mathrm{C}$ & $30-35 \mathrm{C}$ & $35-40 \mathrm{C}$ & $40-44 \mathrm{C}$ \\
\hline Cnemidophorus & - & $3.2 / 3.6$ & $1 / 1$ & $1 / 1$ & $1 / 1$ \\
\hline Dipsosaurus & - & $2.5 / 2.9$ & $1.4 / 1.5$ & $1.4 / 1$ & $1 / 0.7$ \\
\hline Eumeces & - & $1.8 / 1.7$ & $\{-/ 1.3$ & \} & - \\
\hline Gerrhonotus & $3.6 / 2.3$ & $1.7 / 1.6$ & $1 / 1$ & - & $一$ \\
\hline $\begin{array}{c}\text { Sceloporus } \\
\text { July }\end{array}$ & $5.5 / 2.6$ & $1.6 / 1.4$ & $1 / 1.2$ & $1 / 0.7$ & - \\
\hline December & $4.01-$ & $1.9 /-$ & $1 / 1,2$ & $1 / 0$ & - \\
\hline Uma & - & $1.61-$ & $1 /-$ & $1.3 /-$ & $1 /-$ \\
\hline
\end{tabular}

Note: A $Q_{10}$ of 1 indicates a lack of significant change in performance $(P<0.05$, WSRT).

Numerator indicates $Q_{10}$ of burst speed; denominator, distance capacity. 
Table VIII. Distance Running Ability in Small Lizards

\begin{tabular}{|c|c|c|c|c|c|c|c|c|c|}
\hline \multirow[b]{2}{*}{ Species } & \multicolumn{9}{|c|}{ Metres run } \\
\hline & 10 & 15 & 20 & 25 & 30 & 35 & 37.5 & 40 & 44 \\
\hline \multicolumn{10}{|c|}{ Cnemidophorus $(N=14)$} \\
\hline $1 \mathrm{~min}$ & - & - & $\begin{array}{l}11.8 \pm 1.5 \\
(5.4-23.0)\end{array}$ & $\begin{array}{c}32.4 \pm 2.6 \\
(17.6-50.5)\end{array}$ & $\begin{array}{c}49.1 \pm 2.4 \\
(32.9-66.9)\end{array}$ & $\begin{array}{c}48.4 \pm 3.2 \\
(25.2-65.0)\end{array}$ & - & $\begin{array}{c}53.5 \pm 4.2 \\
(23.7-78.0)\end{array}$ & $\begin{array}{c}50.4 \pm 4.0 \\
(22.2-80.3)\end{array}$ \\
\hline $2 \mathrm{~min}$ & - & - & $\begin{array}{c}17.4 \pm 2.1 \\
6.1-33.3)\end{array}$ & $\begin{array}{l}43.3 \pm 2.7 \\
(27.5-62.7)\end{array}$ & $\begin{array}{c}62.5 \pm 2.5 \\
(49.3-79.6)\end{array}$ & $\begin{array}{c}64.5 \pm 2.9 \\
(44.8-79.2)\end{array}$ & - & $\begin{array}{c}69.9 \pm 3.8 \\
(47.4-96.4)\end{array}$ & $\begin{array}{r}63.2 \pm 4.6 \\
(29.1-95.6)\end{array}$ \\
\hline \multirow{2}{*}{$\begin{array}{l}\text { Dipsosaurus } \\
1 \mathrm{~min}\end{array}$} & $(N=20)$ & & & & & & & & \\
\hline & - & $\begin{array}{l}3.8 \pm 0.5 \\
(1.5-6.5)\end{array}$ & $\begin{array}{c}12.1 \pm 0.9 \\
(7.3-19.1)\end{array}$ & $\begin{array}{c}26.5 \pm 1.5 \\
(8.5-36.0)\end{array}$ & $\begin{array}{c}39.4 \pm 1.8 \\
(23.0-49.0)\end{array}$ & $\begin{array}{c}47.6 \pm 1.9 \\
(32.5-63.5)\end{array}$ & - & $\begin{array}{c}46.1 \pm 2.2 \\
(29.1-60.8)\end{array}$ & $\begin{array}{c}41.2 \pm 2.2 \\
(24.5-56.6)\end{array}$ \\
\hline $2 \mathrm{~min}$ & - & $\begin{array}{c}6.5 \pm 0.7 \\
(4.2-10.7)\end{array}$ & $\begin{array}{c}16.8 \pm 1.2 \\
(10.7-27.2)\end{array}$ & $\begin{array}{c}33.5 \pm 1.9 \\
(10.7-49.3)\end{array}$ & $\begin{array}{c}48.4 \pm 2.4 \\
(28.7-66.6)\end{array}$ & $\begin{array}{c}59.8 \pm 2.6 \\
(40.2-86.4)\end{array}$ & - & $\begin{array}{c}59.0 \pm 2.9 \\
(37.5-81.5)\end{array}$ & $\begin{array}{c}52.4 \pm 3.2 \\
(29.8-77.6)\end{array}$ \\
\hline \multicolumn{10}{|c|}{ Eumeces $(N=6)$} \\
\hline $1 \mathrm{~min}$ & -0 & - & $\begin{array}{c}20.9 \pm 1.9 \\
(14.5-26.4)\end{array}$ & - & $\begin{array}{c}36.9 \pm 1.3 \\
(32.1-39.8)\end{array}$ & - & - & $\begin{array}{c}45.8 \pm 1.8 \\
(38.3-49.0)\end{array}$ & - \\
\hline $2 \mathrm{~min}$ & - & - & $\begin{array}{c}33.5 \pm 3.3 \\
(23.0-42.8)\end{array}$ & - & $\begin{array}{c}55.2 \pm 2.5 \\
(45.5-62.0)\end{array}$ & 一 & - & $\begin{array}{c}69.5 \pm 3.9 \\
(55.8-78.8)\end{array}$ & - \\
\hline \multirow{2}{*}{$\begin{array}{l}\text { Gerrhonotus } \\
1 \mathrm{~min}\end{array}$} & $(N=12)$ & & & & & & & & \\
\hline & $\begin{array}{l}6.1 \pm 0.5 \\
(2.7-9.2)\end{array}$ & $\begin{array}{l}11.1+0.9 \\
(5.7-17.6)\end{array}$ & $\begin{array}{c}16.2 \pm 0.9 \\
(12.6-23.0)\end{array}$ & $\begin{array}{c}20.6 \pm 1.1 \\
(15.3-27.5)\end{array}$ & $\begin{array}{c}26.0 \pm 1.5 \\
(18.4-34.4)\end{array}$ & $\begin{array}{c}25.6 \pm 1.2 \\
(19.5-34.4)\end{array}$ & $\begin{array}{c}23.2 \pm 1.4 \\
(16.8-32.1)\end{array}$ & - & - \\
\hline $2 \mathrm{~min}$ & $\begin{array}{c}9.5 \pm 0.7 \\
(4.2-14.5)\end{array}$ & $\begin{array}{l}16.4 \pm 1.2 \\
(9.2-25.6)\end{array}$ & $\begin{array}{l}21.7 \pm 1.2 \\
(16.1-30.2)\end{array}$ & $\begin{array}{c}26.1 \pm 1.3 \\
(20.7-35.2)\end{array}$ & $\begin{array}{c}33.7 \pm 2.1 \\
(23.0-47.0)\end{array}$ & $\begin{array}{c}33.2 \pm 1.7 \\
(28.7-47.0)\end{array}$ & $\begin{array}{c}30.1 \pm 1.8 \\
(22.2-40.5)\end{array}$ & - & - \\
\hline \multirow{2}{*}{$\begin{array}{l}\text { Sceloporus } \\
1 \mathrm{~min}\end{array}$} & $(N=14)$ & & & & & & & & \\
\hline & $\begin{array}{l}6.5 \pm 0.4 \\
(4.6-9.6)\end{array}$ & $\begin{array}{l}13.5 \pm 0.8 \\
(7.7-17.2)\end{array}$ & $\begin{array}{c}20.3 \pm 1.3 \\
(13.4-29.0)\end{array}$ & $\begin{array}{c}25.1 \pm 2.0 \\
(13.8-36.0)\end{array}$ & $\begin{array}{c}30.9 \pm 2.1 \\
(20.7-44.4)\end{array}$ & $\begin{array}{c}32.3 \pm 2.1 \\
(18.4-45.9)\end{array}$ & - & $\begin{array}{c}31.2 \pm 2.8 \\
(23.7-45.9)\end{array}$ & - \\
\hline $2 \mathrm{~min}$ & $\begin{array}{l}10.5 \pm 0.6 \\
(7.1-14.2)\end{array}$ & $\begin{array}{c}20.1 \pm 1.2 \\
(12.2-25.6)\end{array}$ & $\begin{array}{c}27.5 \pm 1.7 \\
(18.4-39.4)\end{array}$ & $\begin{array}{c}32.2 \pm 2.5 \\
(19.9-45.9)\end{array}$ & $\begin{array}{c}37.2 \pm 2.8 \\
(23.0-59.3)\end{array}$ & $\begin{array}{c}40.1 \pm 2.3 \\
(24.5-55.1)\end{array}$ & - & $\begin{array}{c}33.6 \pm 3.0 \\
(26.0-49.3)\end{array}$ & - \\
\hline
\end{tabular}

Mean values \pm SE and (ranges) are reported for each body temperature.

*July. 
does not indicate comparable performance in the other; a good distance runner may have good, average, or poor burst run ability. Likewise, these data do not indicate a specialization of individual animals into sprinters and distance runners.

\section{Discussion}

The burst speeds obtained in this study are substantially the same as those reported from laboratory studies on the same species or genera using motion picture analysis (Snyder 1962; Urban 1965; Pond 1978). These studies and those on other lizards (Sukanov 1974) have found average speeds of 5 to $10 \mathrm{~km} / \mathrm{h}$ for quadripedal locomotion over short distances. In contrast, reported running speeds of lizards in the field, again for many of the same species or genera, are substantially greater, including maximal values of 16 to $29 \mathrm{~km} / \mathrm{h}$ (summarized in Oliver 1955; Belkin 1961; McWhirter 1978). These observations have the advantage of being made in the animal's natural environment, but generally use less sensitive timing methods and often do not record behaviour prior to measurement. The observations reported in this study, consequently, should not be regarded as maximum possible speeds, since they are influenced by acceleration from a standing start. They are, however, repeatable attempts of burst escape over ecologically important distances. Maximum possible speeds would be operationally very difficult to determine and must ultimately be reduced to the single fastest cycle of limb movement. It is clear by any measure, however, that these animals can be very swift. Lizards can run at speeds comparable to mammals over short distances (Gray 1968).

The thermal dependence of these activity modes is substantially less than that anticipated for other biological rate pocesses. Both burst speed and stamina have broad zones of little or no dependence on body temperature in all species examined. This functional independence reported here extends in some cases over the entire thermal range naturally experienced by the species. For example, body temperature in Cnemidophorus murinus varies only between 27 and $40 \mathrm{C}$ on a daily basis (Bennett \& Gorman 1979). The limited information available on the thermal dependence of locomotory behaviour in other reptiles demonstrates similar zones of independence. Maximal sustained walking speeds ( $>10 \mathrm{~min}$ ) are constant between 30 and $40 \mathrm{C}$ in green iguanas (Iguana), but a decline in stamina occurs at lower temperatures (Moberly 1968). Uromastix are able to maintain equivalent speeds over a range of 35 to 42 C (Dmi'el \& Rappeport 1976). Although not directly related to locomotion, striking velocity of gopher snakes (Pitnophis) has a very low thermal dependence between 18 and 33 C (maximum $Q_{10}=1.1$ ), although strike accuracy decreases below $27 \mathrm{C}$ (Greenwald 1974).

Although natural selection has resulted in a low thermal dependence of behavioural capacity, it has not necessarily maximized or optimized performance at normally active body temperatures. High levels of burst activity occur at fieldactive body temperatures in Cnemidophorus, Dipsosaurus, Sceloporus, and Uma. However, there appears to be no particular optimization of capacity at these temperatures. Rather this coincidence only reflects the fact that preferred thermal levels in these species are all $35+C$. There is no decrement in performance at temperatures exceeding these preferred thermal levels. Gerrhonotus, with field active temperatures of 20 to $25 \mathrm{C}$, attains its maximum speeds at $37.5 \mathrm{C}$ and is clearly not functioning optimally at normally experienced thermal levels. There is also a coincidence of running endurance with fieldactive thermal levels in the high-temperature

Table IX. Spearman Rank Correlation Coefficients between Burst Speed and Distance Run (2 min) for Individual Animals at Different Body Temperatures (C)

\begin{tabular}{|c|c|c|c|c|c|c|c|c|c|c|}
\hline & \multirow[b]{2}{*}{$n$} & \multicolumn{9}{|c|}{ Spearman's $\rho$} \\
\hline & & 10 & 15 & 20 & 25 & 30 & 35 & 37.5 & 40 & 44 \\
\hline Cnemidophorus & 14 & - & 一 & $0.61 *$ & 0.52 & 0.51 & 0.13 & - & -0.09 & 0.12 \\
\hline Dipsosaurus & 20 & - & - & $0.58 *$ & 0.34 & -0.18 & -0.31 & - & -0.20 & -0.14 \\
\hline Eumeces & 6 & - & - & 0.26 & - & -0.09 & - & - & - & - \\
\hline Gerrhonotus & 12 & 0.47 & $0.85^{*}$ & $0.63^{*}$ & $0.78^{*}$ & 0.06 & 0.18 & 0.19 & - & 一 \\
\hline $\begin{array}{l}\text { Sceloporus } \\
\text { July }\end{array}$ & 14 & $0.68 *$ & 0.12 & 0.02 & -0.20 & -0.49 & -0.06 & - & $-0.73 *$ & - \\
\hline Dec. & 12 & 0.33 & - & 0.55 & - & -0.25 & 0.03 & - & 0.06 & - \\
\hline
\end{tabular}

*Significant correlation, $P<0.05$. 
lizards, Cnemidophorus, Dipsosaurus, and Sceloporus. However, these values do not coincide in Eumeces or Gerrhonotus, in which maximal capacities occur at body temperatures that are not maintained under field conditions. Thermophilic animals attain high levels of function at preferred thermal levels. However, this competence extends over a much broader thermal range and is not unique to this temperature. Animals with lower field-active temperatures (Eumeces, Gerrhonotus) achieve maximal performance at temperatures outside of their normal experience. The basis of this suboptimal function and its consequences merit further examination.

The functional basis of these interspecific differences in performance and their differential thermal dependence remain to be determined and represent an interesting area of inquiry. The low thermal dependence of distance running capacity evidenced in most species corresponds more closely to that of anaerobic sources of energetic support than to aerobic sources (Bennett 1978). Previous metabolic experiments, however, fail to predict interspecific differences in performance. For instance, the summed energetic capacity of aerobic and anaerobic systems of Eumeces and Sceloporus is nearly identical (Bennett \& Gleeson 1976; Bennett \& Dawson, unpublished data), but the former lizard can run nearly twice as far as the latter. Burst speed appears to be correlated, at least in its thermal dependence, with myosinadenosinetriphosphatase activity of the skeletal muscles (Fig. 1). The activity of this enzyme is closely tied to intrinsic shortening speed of the muscles (Bárány 1967), and consequently to the speed of limb cycling. It is perhaps surprising that a biochemical parameter should so closely mirror behaviour of intact animals, considering the number of physiological systems participating in this behaviour. This correlation will merit further examination.

The techniques employed in this study are relatively simple and inexpensive and can yield repeatable measures of behavioural performance. With slight modifications they could be used to examine a variety of influences on locomotory behaviour, including reproductive condition, incline, substrate type, etc. They also permit an analysis of thermal adaptation in species of diverse environmental conditions. In addition, the repeatability of the performances of individual animals within a group permits a determination of the physiological underpinnings of behavioural differences between individuals.

\section{Acknowledgments}

I thank Todd T. Gleeson for his very extensive assistance with these experiments, and for his comments and those of R. W. Putnam and J. M. Stearns on the manuscript. Financial support for this study was provided by NSF Grants PCM 75-10100 and PCM 77-24208, and NIH Grant 1 K04AM00351-01.

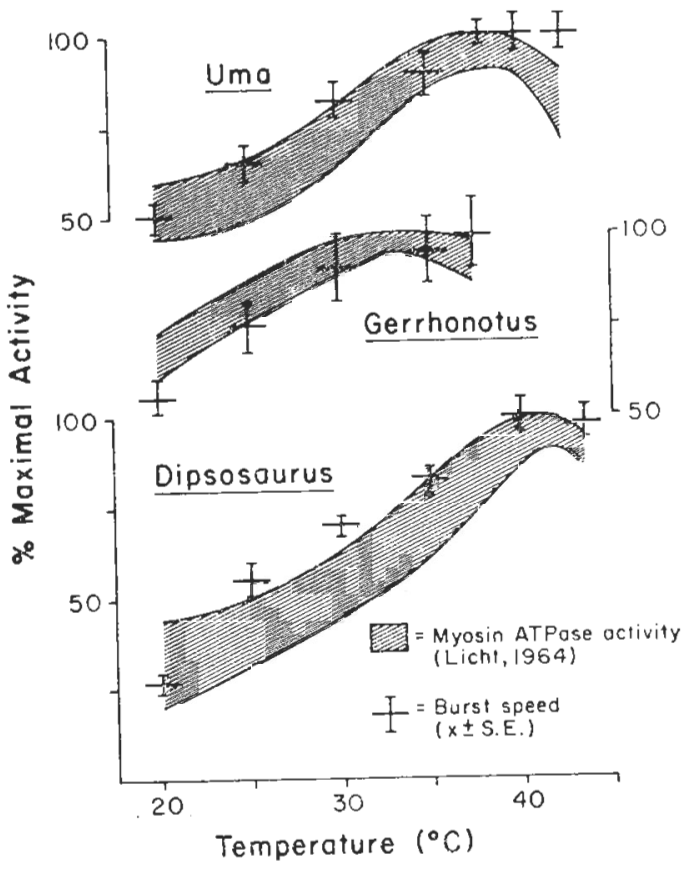

Fig. 1. The thermal dependence of burst speed and myosin adenosinetriphosphatase activity in three species of lizards. Shaded bands indicate the range of values for enzyme activity reported by Licht (1964). Average burst speeds with standard errors are reported from this study. Both factors are normalized to maximum activity observed.

\section{R E F E R E N C E S}

Bárány, M. 1967. ATPase activity of myosin correlated with speed of muscle shortening. J. gen. Physiol., 50, 197-218.

Belkin, D. A. 1961. The running speeds of the lizards Dipsosaurus dorsalis and Callisaurus draconoides. Copeia, 1961, 223-224.

Bennett, A. F. 1978. Activity metabolism of the lower vertebrates. Ann. Rev. Physiol., 40, 447-469.

Bennett, A. F. \& Dawson, W. R. 1976. Metabolism. In: Biology of the Reptilia, Vol. 5 (Physiology A) (Ed. by C. Gans \& W. R. Dawson), pp. 127-223. London and New York: Academic Press.

Bennett, A. F. \& Gleeson, T. T. 1976. Activity metabolism in the lizard Sceloporus occidentalis. Physiol. Zool., 49, 65-76. 
Bennett, A. F. \& Gorman, G. C. 1979. Population density and energetics of lizards on a tropical island. Oecologia, 42, 339-358.

Bennett, A. F. \& Licht, P. 1972. Anaerobic metabolism during activity in lizards. J. comp. Physiol., 81, 277-288.

Brattstrom, B. H. 1965. Body temperatures of reptiles. Am. Midl. Nat., 73, 376-422.

Cloudsley-Thompson, J. L. 1971. The Temperature and Water Relations of Reptiles. Watford, England: Merrow.

Cowles, R. B. \& Bogert, C. M. 1944. A preliminary study of the thermal requirements of desert reptiles. Bull. Am. Mus. Nat. Hist., 83, 265-296.

Dawson, W. R. 1967. Interspecific variation in physiological responses of lizards to temperature. In: Lizard Ecology: A Symposium (Ed. by W. W. Milstead), pp. 230-257. Columbia, Mo.: University of Missouri Press.

Dawson, W. R. 1975. On the physiological significance of the preferred body temperatures of reptiles. In: Perspectives in Biophysical Ecology (Ed. by D. M. Gates \& R. B. Schmerl), pp. 443-473. New York: Springer-Verlag.

DeWitt, C. B. 1967. Precision of thermoregulation and its relation to environmental factors in the desert iguana, Dipsosaurus dorsalis. Physiol. Zool., 40, 49-66.

Dmi'el, R. \& Rappeport, D. 1976. Effect of temperature on metabolism during running in the lizard Uromastix aegyptius. Physiol. Zool., 49, 77-84.

Fitch, H. S. 1955. Habits and adaptations of the great plains skink, Eumeces obsoletus. Ecol. Monogr., 25, 59-83.

Gleeson, T. T. 1979. The effects of training and captivity on the metabolic capacity of the lizard Sceloporus occidentalis. J. comp. Physiol., 129, 123-128.

Gray, J. 1968. Animal Locomotion. New York: W. W. Norton.

Greenwald, O. E. 1974. Thermal dependence of striking and prey capture by gopher snakes. Copeia, 1974, 141-148.
Licht, P. 1964. The temperature dependence of myosinadenosinetriphosphatase and alkaline phosphatase in lizards. Comp. Biochem. Physiol., 12, 331-340.

McGinnis, S. M. 1966. Sceloporus occidentalis: Preferred body temperature of the western fence lizard. Science, N.Y., 152, 1090-1091.

McWhirter, N. 1978. Guinness Book of World Records. New York: Bantam Books.

Moberly, W. R. 1968. The metabolic responses of the common iguana, Iguana iguana, to walking and diving. Comp. Biochem. Physiol., 27, 21-32.

Norris, K. S. 1953. The ecology of the desert iguana Dipsosaurus dorsalis. Ecology, 34, 265-287.

Oliver, J. A. 1955. The Natural History of North American Amphibians and Reptiles. New York: Van Nostrand.

Pond, C. M. 1978. The effect of tail loss on rapid running in Dipsosaurus dorsalis. Am. Zool., 18, 612 (Abst.).

Precht, H., Christophersen, J. \& Hensel, H. 1955. Temperatur und Leben. Berlin: Springer Verlag.

Prosser, C. L. 1973. Temperature. In: Comparative Animal Physiology (Ed. by C. L. Prosser), pp. 362-428. Philadelphia: Saunders.

Siegel, S. 1956. Nonparametric Statistics for the Behavioral Sciences. New York: McGraw-Hill.

Snyder, R. C. 1962. Adaptations for bipedal locomotion of lizards. Am. Zool., 2, 191-203.

Sukanov, V. B. 1974. General System of Symmetrical Locomotion of Terrestrial Vertebrates and Some Features of Movement of Lower Tetrapods. New Delhi: Amerind.

Tucker, V. A. 1967. The role of cardiovascular system in oxygen transport and thermoregulation in lizards. In : Lizard Ecology: A Symposium (Ed. by W. W. Milstead), pp. 258-269. Columbia, Mo.: University of Missouri Press.

Urban, E. K. 1965. Quantitative study of locomotion in teiid lizards. Anim. Behav., 13, 513-529.

(Received 25 June 1979; revised 19 September 1979; MS. number: A2337) 